\title{
レースウェイ形成に関する冷間模型実験*
}

\author{
羽田野道春 ${ }^{* *}$. 福田充一郎 ${ }^{* *}$. 竹内 正幸 $* * *$
}

\section{An Experimental Study of the Formation of Raceway Using a Cold Model}

\author{
Michiharu Hatano, Mitsuichiro FukUda, and Masayuki TakeUchI
}

\section{Synopsis:}

The raceway formed in front of a tuyere is one of decisive factors to operate a blast furnace stably and efficiently, because the gas distributions from the raceway and the descent of the burden are greatly affected by the characteristics of the raceway.

There are, however, many unknown facts about the formation of the raceway and incidental phenomena. This study has been carried out for the purpose of solving some of them using a cold model and an experimental blast furnace.

In this paper, some results obtained through cold model experiments are presented.

The summary of the results is as follows:

1) Particles in the raceway rotate around at high speed, colliding with rotating particles or the raceway wall and some of them are reduced in size.

2) A lot of fine particles formed in the raceway accumulates on the surface of the raceway in front of the tuyere.

3) Under a condition of reduced particle size in front of tuyere, the raceway is enlarged, especially upwards along the furnace wall.

4) The depth of the raceway can be expressed by the relationship between the raceway factor $\left(P \cdot V^{2}\right.$. $\left.\rho_{\mathrm{go}} / g \cdot d_{s} \cdot \rho_{s} \cdot S^{2}\right)$ and the penetration factor $\left(D_{R} / D_{T}\right)$.

\section{1. 緒}

言

高炬の羽口前には, 羽口からの送風によつて, いわゆ るレースウェイと呼ばれるコークスおよびガスの循環流 から成る笁間が形成されるが，レースウェイとその周辺 の状況は，炉下部におけるガス流れ，装入物の荷下り， 付着物の生成などと密接な関係があり, これが高炉の生 産性および炉況に対して大きな影響を及ぼすと考えられ る.

レースウェイ形成に影響を及ぼす要因は数多いが，特 に, 装入コークスの性状, 送風条件, 羽口径, 羽口角度 などの影響が大きい.

レースウェイに関する研究は古くから行なわれてお り，これまでに数多くのモデル実験結果が報告1) 5)され ているが，単にレースウェイの大きさを規定する要因の 解析に止まつている. そこで，著者らは，二次元冷間模 型と実物大の高炉下部実験炉を作製し，レースウェイ形
成に影響を及ぼす諸要因の影響を総合的に把握するとと もにレースウェイからのガス流れ，炉況などの現場的な 現象の解明を目的に実験を進めて来たが，本報告では二 次元冷間模型で得られたレースウェイ形成に対する 2,3 の知見について報告する.

\section{2. 実験装置および実験方法}

実験装置の概略を Fig. 1 に, 外観写真索 Photo. 1 に示す. 模型は幅 $45 \mathrm{~mm}$, 長さ $920 \mathrm{~mm}$, 高さ $1000 \mathrm{~mm}$ の高炉下部コークベッドに関する二次元模型で, 模型の 両面に透明アクリル板を張り，レースウェイ形状の測定 および写真撮影が 可能である. 模型の下端より約 200 $\mathrm{mm}$ の位置に径および角度可変の円型羽口が 1 本挿入 されているが, 通常, 羽口角度は水平, 径 $18 \mathrm{~mm}$, 突出 長さ $60 \mathrm{~mm}$ である.

模型裏面には 115 力所に静圧測定孔を設け模型内の圧 力分布を測定する。また, 層頂に設置した風速計により,

* 昭和 47 年 10 月本会講演大会にて発表＼cjkstart昭和 50 年 4 月 21 日受付 (Received April 21，1975)

** 住友金属工業(株) 中央技術研究所 (Central Research Laboratory, Sumitomo Metal Industries, Ltd.

1-3 Nishinagasu Hondōri Amagasaki 660)

*** 住友金属工業(株)小會製鉄所 (Kokura Works, Sumitomo Metal Industries, Ltd.) 
層頂での流速分布を実測する. 羽口風量はバルブおよび 流量計によつて制御する.

実験に用いた充填物は, Table 1 亿示すように大豆, 小装, 粟, 砂 1 , 砂 II, 砂 106 種類である.なお, 本

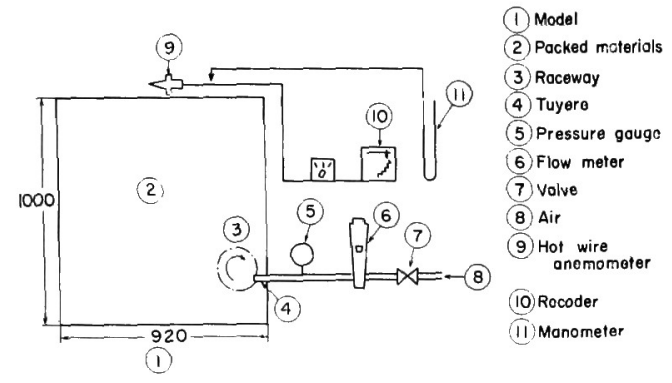

Fig. 1. Schematic diagram of experimental appratus.

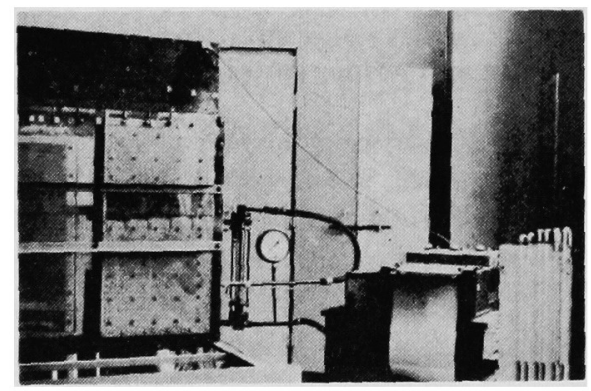

Photo. 1. Experimental appratus.

Table 1. Properties of charged materials.

\begin{tabular}{l|c|c|c|c}
\hline & $\begin{array}{c}\text { Particle } \\
\text { size } \\
d s(\mathrm{~mm})\end{array}$ & $\begin{array}{c}\text { Density } \\
\rho s \\
\left(\mathrm{~g} / \mathrm{cm}^{3}\right)\end{array}$ & $\begin{array}{c}\rho s \cdot d s \\
\left(\mathrm{~g} / \mathrm{cm}^{2}\right)\end{array}$ & Symbols \\
\hline Soya bean & 7.5 & 1.22 & 0.915 & $\triangle$ \\
Wheat & 3.8 & 1.36 & 0.513 & $\square$ \\
Millet & 1.5 & 1.30 & 0.195 & $\times$ \\
Sand I & $0.5 \sim 1.0$ & 2.59 & 0.194 & $\bigcirc$ \\
Sand II & $1.0 \sim 2.0$ & $\prime \prime$ & 0.389 & $\bigcirc$ \\
Sand III & $2.0 \sim 3.0$ & $\prime \prime$ & 0.640 & $\bigcirc$ \\
\hline
\end{tabular}

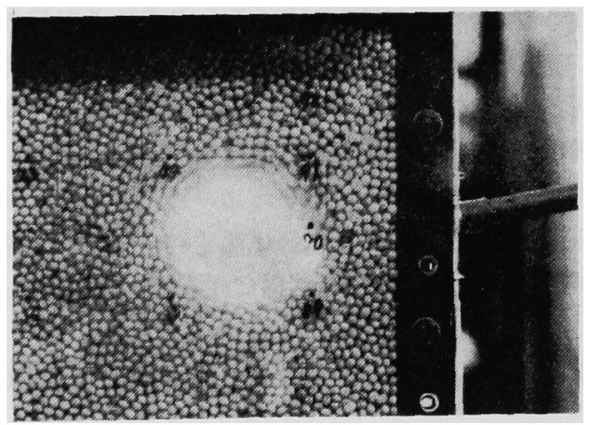

Photo. 2. The raceway in front of a tuyere.
装置は前述のように幅 $45 \mathrm{~mm}$ の平板模型であるために， 壁面効果によつてガスおよび粒子の三次元的な動きが抑 制されるため，実際のレースウェイを完全に再現できて いるとは思われないが，レースウェイ形成に及ぼす諸要 因の影響を定性的に把握するために二次元模型による実 験を行なつた。

\section{3. 実 験 結 果}

装置内に圈体粒子を充填し，送風を開始するとやがて 羽口前粒子が動き始め, さらに送風量を增すと Photo. 2 に示すようなレースウェイが形成される.

内部では粒子が高速度で旋回しているが，レースウェ イの形状, 大きさ，および粒子の挙動は送風量, 充填物 の性状によつて異なる.

\section{1 レースウェイ内粒子の挙動}

Fig. 2 は, 送風量が $23.5 l / \mathrm{sec}$ の時のレースウェイ 内部老運動する粒子の定性的な速度分布を，大豆 (7.5 $\mathrm{mm})$ と砂 $(1 \sim 2 \mathrm{~mm})$ とで比較したものである. 図の 等速度線は種々のシャッター速度で写真撮影を行ない, その画面で運動粒子が見掛上静止している境界線を示す ものである. 粒子の移動層を罒の椂に 5 分割して考える と, 大部分の粒子は $\mathrm{A} \rightarrow \mathrm{B} \rightarrow \mathrm{C} \rightarrow \mathrm{D}$ の経路で上向き旋回 流を形成するが，球状に近いレースウェイ在形成した大 豆の場合，Eの領域の粒子が図の分岐点を境にしてゆつ くりと羽口側へ移行する現象が見られた.

一方、レースウェイ底面がフラットに前方へ発達した 砂の場合, 下向旋回流は全く無く, 上向旋回のみであつ た、 $\mathrm{A}$ および $\mathrm{B}$ 領域において等速度線が接近している が、この領域では移動層の層厚が薄く, 移動層表面の高 速で移動する粒子によつて他の粒子が，レースウェイ外 周部に押しつけられ密充埴となつているのがわかる、C, $\mathrm{D}$ に行くに従つて粒子の移動速度は全般に遅くなり移動 層の層愿が㕌くなる、D領域の粒子の一部は羽口上部に 衝突した後羽口前に供給される. 大豆と砂の運動状態の 比較では, 大豆の方が円形に近い循環流を形成するのに 対して, 砂の場合三危形状の軌跡を描く。また, 砂の方 が同一風量に対する粒子の移動速度が速い.

このように，レースウェイ内で粒子の旋回流が形成さ れると，移動粒子間およびレースウェイ壁との衝突によ つて粒子の破砕と蓄積とが繰り返し進行すると考えられ る. 特に, B 領域は高速で移動して来た粒子が壁に衝突 する位置であるので粒子の破砕が起こりやすい. Fig. 3 は, $23.5 \mathrm{l} / \mathrm{sec}$ の送風学約 $10 \mathrm{~min}$ 間行なつた後に, 各 領域に存在している粒子を一定量採取しその中に含まれ ている微粒子の割合を示したものである. 大豆, 砂の両 


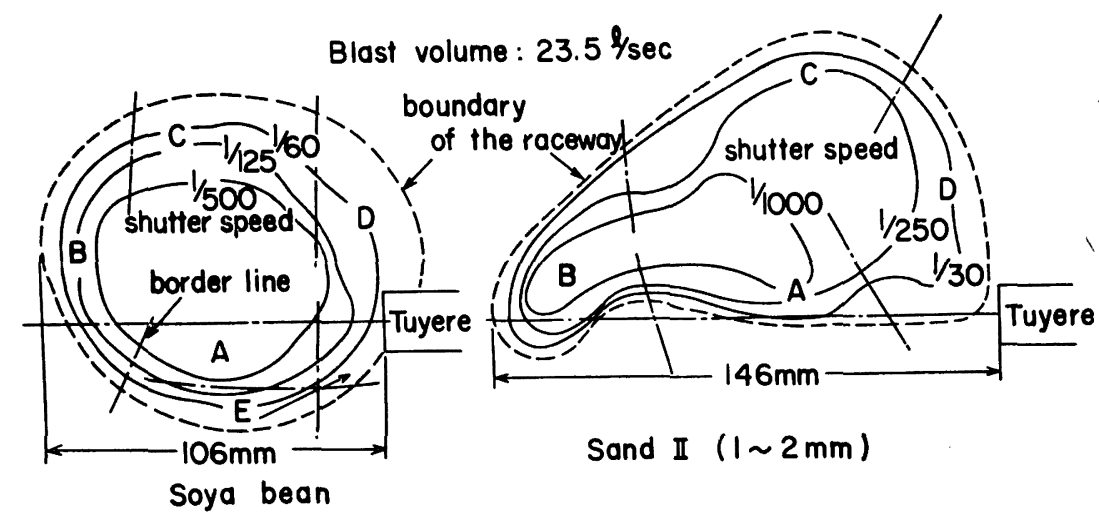

Fig. 2. Velocity distributions of the particles rotating in the raceway.

者とも羽口対面 $\mathrm{B}$ の領域借微粒子が蓄積されやすい傾向 にあるが, 粒子径が小さくて旋回速度が大きい砂の場合, B 領域における微粒子の集積が特に著しく, $0.25 \mathrm{~mm}$ 以 下の粒子が $54 \%$ を占奶ていた。

一方, 粒子径が大で粒子の旋回速度の小さな場合, 破 砕も少ないが，破砕された微粒子はレースウェイ外周部

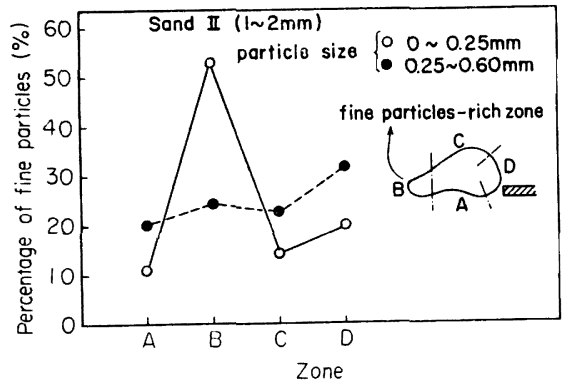

Fig. 3. Distribution of the fine particles around the raceway.
に比較的均一に分布している.

\section{2 レースウェイ近傍の圧力分布}

レースウェイ近傍の压力分布は，レースウェイ境界粒 子層の粒度構成と充㯖状態に依存している.

Fig. 4 は，送風量が $23.5 \mathrm{l} / \mathrm{sec}$ 時のレースウェイ近 傍の静压分布を砂と大豆とで比較したものである. 図中 にレースウェイ境界線を破線で示したが，図から明らか なようにレースウェイ境界はある一定の圧力で支えられ ている事がわかる。この圧力は，送風条件および充壃物 の性状によつて異なる。また，羽口対面のB領域では等 圧線が接近しており，他の領域に比して圧力勾配が大で ある. 特に精子径の小さい砂を充填した場合，その傾向 が強く, 大豆と比較するとB領域での圧力損失の増大が 顕著である. 圧力損失には, 通気抵抗と流速の両者が関 係するが，前述のように粒子径の小さい砂を充填した場 合，羽口対面のレースウェイ境界層 (B 領域)付近に特に 微粒子が集まりやすい傾向にあり，他の領域に比較して 通気抵抗の増大が大きいと考えられる.したがつて，砂

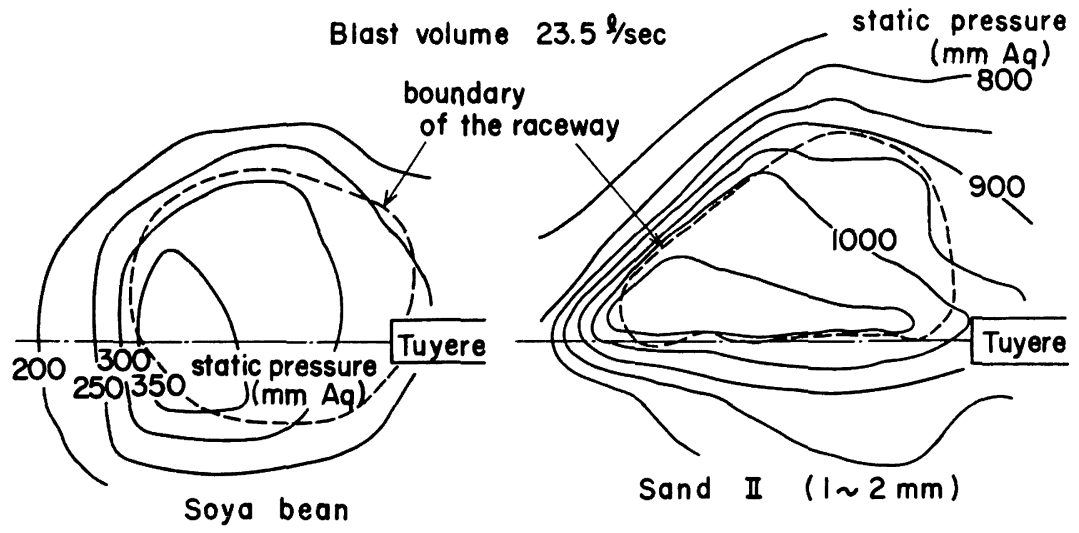

Fig. 4. Static pressure distributions around the raceway. 
の場合に見られたB領域における著しい圧力損失は，羽 口からの衝風が B 領域に衝突した際にB 領域より比較的 通気性の良い炉壁側へ主流の方向が变化したために生じ たと定性的に考えられる. 現象としては，B領域から C, D方向への粒子の動きが活発化し，レースウェイは全体 に大きくなるとともに炉壁に沿つて発達する傾向が観察 された。

一方，大豆の場合，レースウェイ境界付近の通気性が 良好でかつ比較的均一であるために，ガスの偏流が少な く,球状に近いレースウェイが形成されたと考えられる。

\section{3 レースゥェイ形成に及ぼす諸要因}

レースウェイ形成の力学的な考察は多くの研究者によ つてなされているが，ElLIOT'1)，WAGSTAFF')などによれ ば，レースウェイは衝風による揚力とレースウェイ天井 壁の重力との釣合いであるとしている。一定の性状を有 する粒子を充填し，送風量を增加するとレースウェイ深 さ $\left(D_{R}\right)$ とレースウェイ高さ $\left(H_{R}\right)$ は増加の傾向を示す.

そこで,第一に，性状の異なる種々の充填物に対して， レースウェイ深さを羽口1 本あたりの衝風運動量との関 係でまとめると Fig. 5 のようになる. 罒に示されるよ うに，銘柄ごとのレースウェイ深さと衝風運動量との間 にはほぼ直線的な関係が成立し，衝風運動量がレースウ ェイ樑さを規定する一要因であることは明らかである.

一方，銘柄ごとの直線の勾配はすべて異なるが，これ は充填物の性状の差が関係していると考元られる. 充壋 物の性状としては，特に粒子径，密度の影響が大きい。 その他，羽口径および角度の影響も考虑する必要がある のでこれらの影響について検討した。

\section{$3 \cdot 3 \cdot 1$ 粒子径の影響}

Fig. 6 の a), b) は密度が等しくて, 粒子径の異なる砂 I $(0.5 \sim 1 \mathrm{~mm})$ と砂 $\mathbb{I I}(2 \sim 3 \mathrm{~mm})$ のレースウェイ形状を

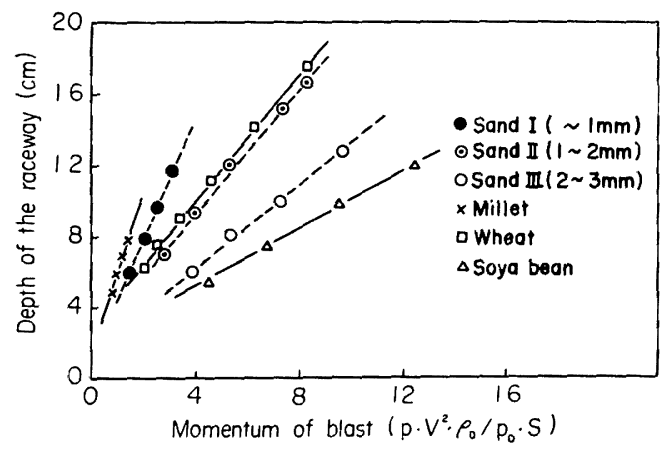

Fig. 5. Relationship between the momentum of blast and the depth of the raceway with various charged materials.
比較したものである，両者ともに，送風量を增すに従い レースウェイは拡大する. しかし, 粒子径の大きい砂 II の場合, レースウェイは羽口前方に発達するのに対して, 粒子径の小さい砂 I の場合, レースウェイは前方へ拡大 するとともに上方への発達が著しくなり，18l/ sec の送 風量ではレースウェイ天井部の粒子が炉壁に沿つて, 間 欠的に上方へ吹き上げられる，いわゆる吹き抜け現象を 呈する. また, 砂 II $(1 \sim 2 \mathrm{~mm})$ の場合でも, 砂 I に近い レースウェイ形状を呈し, 送風量 $29 l / \mathrm{sec}$ で吹き抜け を起こした。

以上, 砂 3 種類のレースウェイ深さを衝風運動量との 関係でまとめると Fig. 7 のようになる. また, 図中に 吹き抜け限界曲線它示した.

図から，粒子径が小さい注ど同一の衝風運動量に対す るレースウェイ深さは大となり, かつ, 少ない送風量で 吹き抜けを起こすことがわかる.

\section{3 .2 粒子密度の影響}

Fig. 8 は, 粒子径が $1 \sim 2 \mathrm{~mm}$ とほほ等しく, 密度の 異なる砂 I (密度 : $2.59 \mathrm{~g} / \mathrm{cm}^{3}$ ) と栗 (密度 : $1.30 \mathrm{~g} /$ $\left.\mathrm{cm}^{3}\right)$ のレースウェイ深さを衝風運動量の関係でまとめ たものである. 粒子径が等しくても, 密度の小さいもの ほど，同一の衝風運動量に対するレースウェイ深さは大

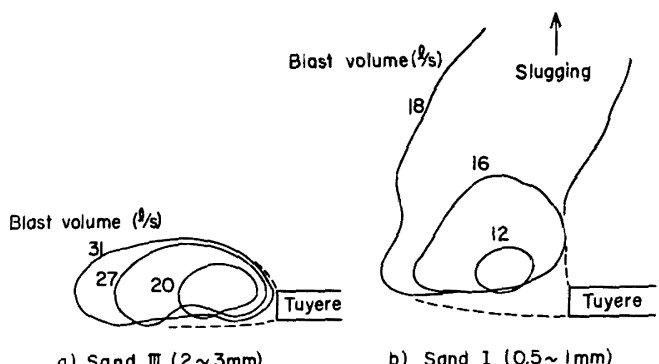

a) Sand III $(2 \sim 3 \mathrm{~mm})$

b) Sand I $(0.5 \sim 1 \mathrm{~mm})$

Fig. 6. Effect of the particle size of charged materials on the shape of the raceway.

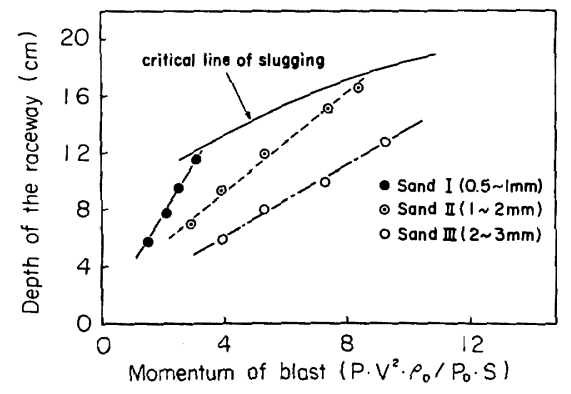

Fig. 7. Effect of the particle size of charged materials on the depth of the raceway. 
となり，小さい衝風運動量で吹き抜けを起こす.

\section{$3 \cdot 3 \cdot 3$ 羽口径の影響}

レースウェイ形状に対しては, 送風量, 充堭物の性状 以外に羽口径も重要な要因である.

Fig. 9 は，大豆を充填物とし羽口径を变更した時の影 響を示す. 図のように，送風量および充埧物の性状が一 定でも羽口径によつてレースウェイ深さは異なり, 羽口 径の小さいほどレースウェイ深さは大となる。

羽口角度については，一般に実炉においては，下向き 0〜10 の範囲で操業されているが，羽口角度がレースウ ェイ形状およびレースウェイからのガス流れに及ぼす影 響は必ずしも明らかでない，そこで，極端な場合として 羽口角度が上向き $10^{\circ}$ と下向き $10^{\circ}$ の場合を比較検討し

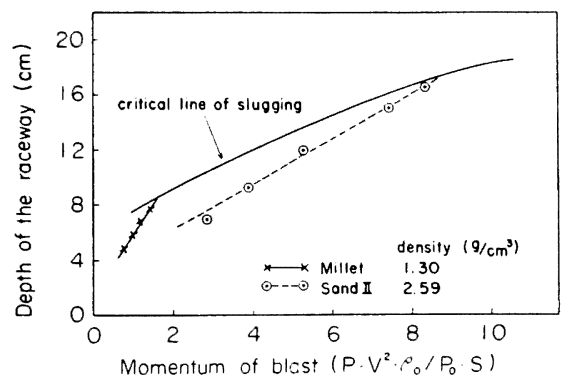

Fig. 8. Effect of the density of charged materials on the depth of the raceway.

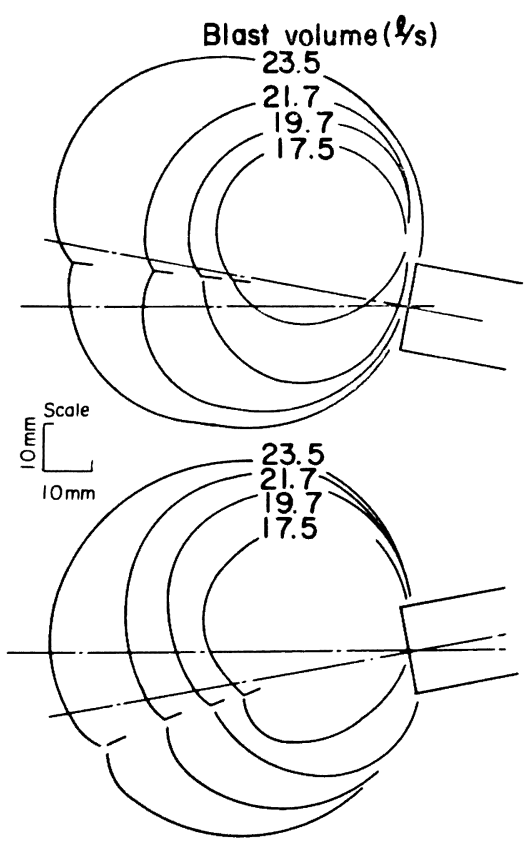

た. 充填物は大豆で羽口径 $18 \mathrm{~mm}$, 羽口突出長さ $6 \mathrm{~cm}$ である.レースウェイ形状の比較を Fig. 10 に示す. 図 に見られるように，レースウェイは羽口の中心線を軸に 発羊する性質があるので，水平軸を基準に考えるならば 羽口角度が上向きの場合レースウェイは上方に発達し, 羽口角度が下向きの場合には下方への発達が大となる. しかし，羽口中心軕を基準に考皇ると，レースウェイ形 状およびレースウェイ深さとも，両者の間には差が認め られない. 次に,レースウェイからのガス流れについて， Fig. 11 に示す樣な装置の垂直断面における等圧線図か ら推定した、流体は等圧線に対して垂直方向に流れてい ると考えられる. 今, レースウェイ境界を示す等圧線を 等間隔で数分割し，それからの流線を図の様に描いた。

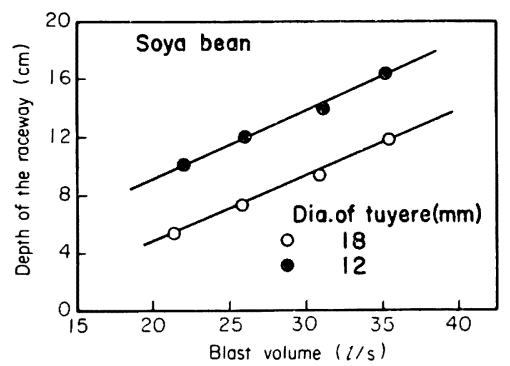

Fig. 9. Effect of the tuyere diameter on the depth of the raceway.

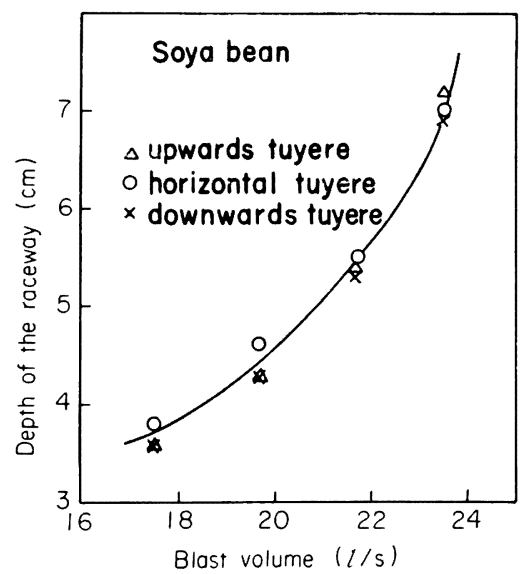

Fig. 10. Effect of the tuyere angle on the shape and depth of the raceway. 

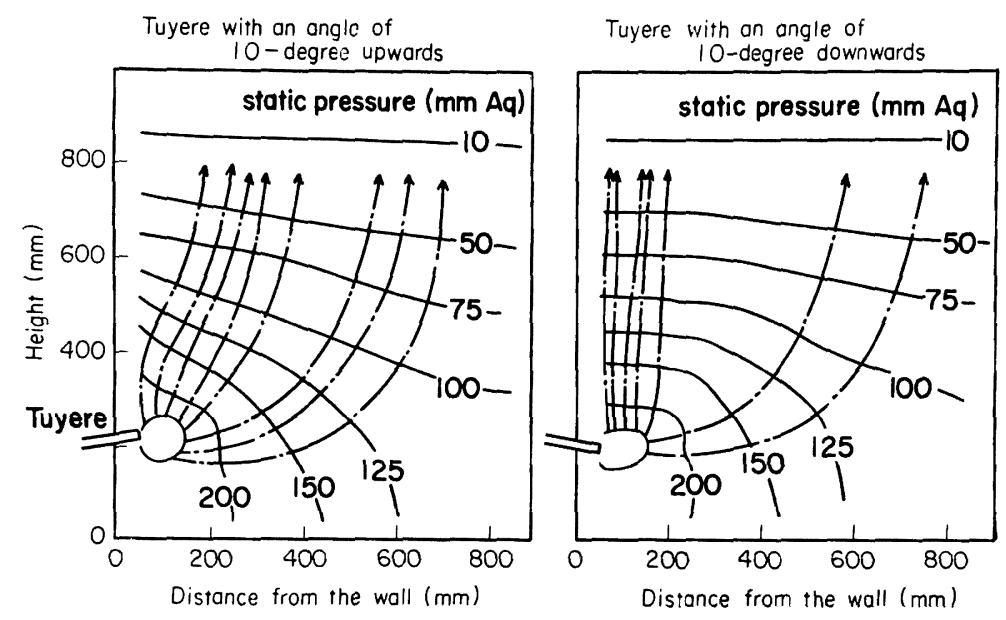

Fig. 11. Effect of the tuyere angle on distributions of static pressure and flow patterns of air.

羽口角度上向きの場合, 师芯方向での流線密度が大とな つているのに対し，羽口角度下向きの場合，炉壁での流 線密度が大である.流線密度の分布から考元て定性的に は羽口の下向き角度が大きいほど，レースウェイ直上で 惊壁流が発達しやすいといえる.

上述のように，レースウェイ形状に影響を及ぼす要因 として, 衝風運動量, 粒子径, 粒子密度, 羽口径が上げ られるが、レースウェイ深さを定量的に評価するために， レースウェイ深さに関して, 下記の無次元量を導入して 検討した.レースウェイ深さ $D_{R}$ が羽口径 $D_{T}$ と相関を もつことから， $D_{R}$ を $D_{T}$ で割つて無次元化しこれを Penetration Factor と定義する.

Penetration Factor $=\left(D_{R} / D_{T}\right)$

また,レースウェイ深さは，粒子 1 個が衝風から受け る運動量に比例し, 粒子の重力に逆比例すると仮定して, 両者の比を Raceway Factor と定義する.

すなわち, 直径 $d_{s}$, 密度 $\rho_{s}$ の粒子 1 個が衝風から受 ける運動量は，粒子の断面積に比例するとすると

$$
\frac{\rho_{g} \cdot V \cdot v}{S} \times \pi\left(\frac{d_{s}}{2}\right)^{2}=\frac{P}{P_{0}} \cdot \rho_{g_{0}} \cdot \frac{V^{2}}{S^{2}} \times \pi\left(\frac{d_{s}}{2}\right)^{2}
$$

となる、また，粒子 1 個の重力は

$$
\rho_{s} \cdot \frac{3}{4} \pi\left(\frac{d_{s}}{2}\right)^{3} \cdot g
$$

であるから，(1)，(2)式より

Raceway Factor $=\left(P \cdot \rho_{g_{0}} \cdot V^{2}\right) /\left(P_{0} \cdot \rho_{s} \cdot d_{s} \cdot S^{2} \cdot g\right)$ と定義される.

なお，両 Factor は WAGSTAFF らの式と本質的には 変らない.この $2 つ の$ 無次元量を用いて，前述のデータ

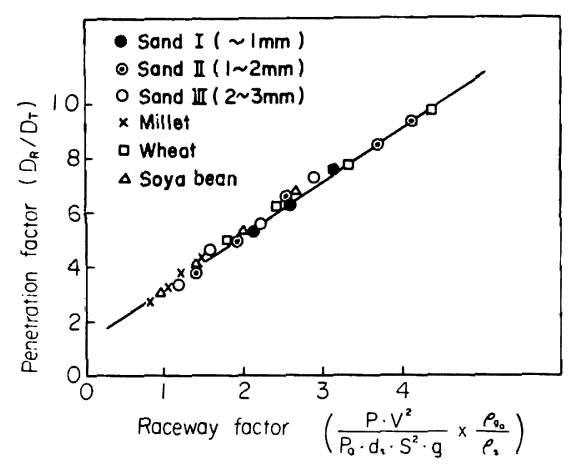

Fig. 12. Relationship between the raceway factor and the penetration factor.

一を整理し直すと Fig. 12 の関係が得られる.図のよう に, 両者の関係を近似的に 1 つの直線で表現することが できる.しかし，英国の実炉データー3) から，両無次元 量を計算してプロットすると，冷間模型で得られた両者 の関係を示す直線からずれる。その理由としては，

a 、実炉では，羽口前でガスの体積变化が起こるが， 冷間模型ではこの点が考慮されていない.

b ．また，羽口前のコークスの粒子径を装入時の粒子 径に比例するとして，その 6 割の值で代表させている.

c. 装置上，ガスおよび粒子の 3 次元的な拡がりが抑 制される.

などがあげられる.

したがつて，実炉でのレースウェイ深さを定量的に把 握するには，コークスの燃焼を伴い，かつ，壁の影響の ない熱間モデルによる検討が必要であることを示唆して いるが，この点については実物大の高炉下部実験炉によ 


\section{る検討結果で報告する。}

以上のように，コークスの燃焼が伴つた場合の問題点 はあるが，レースウェイ深さを前記無次元量の関係で一 応表現し得ることが判明した。しかし，レースウェイの 高さについての報告は，解析の困難なこともあつて，現 在の所ほとんど見られない.

Fig. 13 は，レースウェイ高さとレースウェイ深さと の関係を示すものである.レースウェイ深さが大になれ ばレースウェイ高さも大になるという一般的な傾向は見 られるが，必ずしも 1:1 の対応関係にはない。

また，全ケースを通じての特徵的な傾向として，レー スウェイ深さがある程度まで大きくなると，レースウェ イの上方への発達が著しくなり, やがて天井部の粒子を 吹き上げる現象を呈する点があげられる．今，この傾向 を一般化するために，レースウェイ深さ $\left(D_{R}\right)$ とレース ウェイ高さ $\left(H_{R}\right)$ に各々 $\left(\rho_{w} / \rho_{s} \cdot d_{s}\right)$ をかけて㓻次元化 しこれらを Depth · Factor と Height · Factor と定 義して, 両者の関係を求めると Fig. 14 のようになる. 全データーが，かなりよく 1 つの曲線上にのり，レース ウェイの上方への発達および吹き抜け傾向がわかる.

Depth · Factor が 20 付近で上部への発達が著しくな り，50前後で吹き抜けを起こす．このように，レースウ ェイ深さと高さの関係は，レースウェイからのガスの吹 き出し状態を示す一指標であり，炉況と密接な関係を持 つと思われるので, 検討不充分であるが今後の検討課題 としてその一例を示した.

\section{4. と め}

高炉操業上極めて重要な意味を持つが，現在の所不明 確な点の多い高炉下部現象の解明の一端として, 二次元 冷間模型により，レースウェイ形成に閔する検討を行な つた結果，以下の点が明らかとなつた。

1) レースウェイ内では粒子が高速で旋回しており， 旋回粒子間およびレースウェイ壁との衝突により粒子の 破砕が起こるが，破砕された微粒子は羽口対面のレース ウェイ先端付近に集積し，この部分の通気性を阻害す る.

2) レースウェイの境界壁は一定の圧力で支兑られて いる.

3) レースウェイの大きさは, 羽口からの衝風運動量 に比例し, 充填物の粒子径, 密度, 羽口径に逆比例する が，充填物の粒子径が小さい場合，レースウェイは羽口 上方への発達が著しく炉壁に沿つて吹き抜けを起こしや すくなる。

4) レースウェイ深さを Raceway·Factor と Penetra-

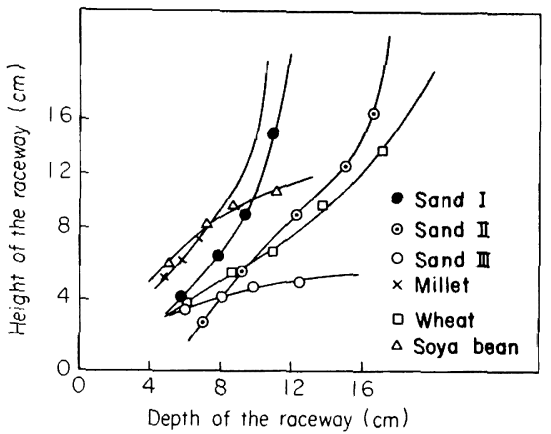

Fig. 13. Relationship between the depth and the height of the raceway with various charged materials.

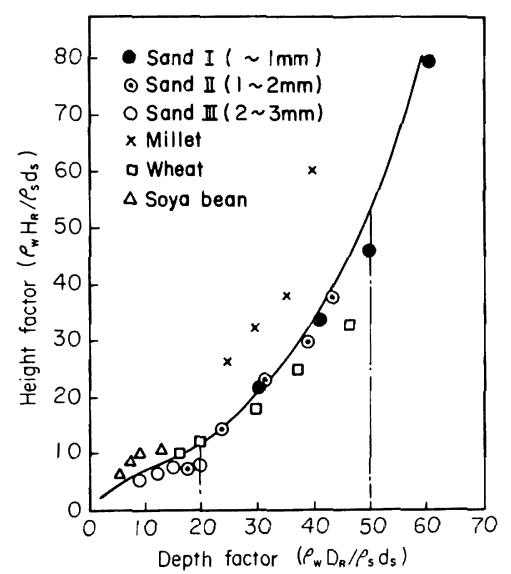

Fig. 14. Relationship between the depth factor and the height factor.

tion・Factor の関係から求めることができるが，実炉へ の適用に対しては，現在の所若干問題があり，熱間モデ ルによる解析および実炉データの蓄積が必要である.

\section{記号}

$P$ : 送風压力 $\left(\mathrm{g} / \mathrm{cm}^{2}\right)$

$V:$ 送風量 $(l / \mathrm{sec})$

$S:$ 羽口断面積 $\left(\mathrm{cm}^{2}\right)$

$\rho_{g_{0}}: 20^{\circ} \mathrm{C}, 1 \mathrm{~atm}$ での空父密度 $\left(\mathrm{g} / \mathrm{cm}^{3}\right)$

$\rho_{s}:$ 粒子密度 $\left(\mathrm{g} / \mathrm{cm}^{3}\right)$

$g:$ 重力加速度 $\left(\mathrm{cm} / \mathrm{sec}^{2}\right)$

$D_{T}:$ 羽口径 $(\mathrm{cm})$

$D_{R}:$ レースウェイ深さ $(\mathrm{cm})$

$H_{R}:$ レースウェイ高さ $(\mathrm{cm})$

$\rho_{W}$ : 水の密度 $\left(\mathrm{g} / \mathrm{cm}^{3}\right)$ 


\section{交献}

1) J. F. Eleror, et al.: J. Metals, (1952) July, p. 709

$2) J . B$. Wagstaff, et al. : Blast Furnace, Coke Oven and Raw Materials Proceedings, 15
(1956), p. 95

3) J. TAYlOR, et al. : JISI, 187(1957), p. 330

4) V. G. Manchinski, et al. : Stal in English, (1960) Sept., p. 629

5) C. C. Gardner : Trans. AIME, 218(1960), p. 423 